\title{
The European Court of Justice, Labour Law and ILO Standards
}

\author{
Brian BERCUSSON
}

\section{Summary}

Two questions are addressed in this paper: (1) how much does, or will, the ECJ in exercising its jurisdiction in the field of labour law look to international standards; (2) how far does, or will, the ECJ seek to go further or provide less?

The paper reviews the sources from which the ECJ has drawn in exercising its labour law jurisdiction include the Treaties, EU secondary legislation and the general principles of the EU legal order.

The Preamble to the Community Charter of the Fundamental Social Rights of Workers of 1989 refers to" inspiration... drawn from the Conventions of the ILO". The Preamble to the EU Charter of Fundamental Rights 2000 reaffirms "...rights as they result, in particular, from the... international obligations common to the Member States". The absence of an explicit reference in the EU Charter to ILO labour standards is notable.

The European Court of Justice states that fundamental rights form an integral part of the general principles of law and international treaties can supply guidelines. The ECJ finally cited the EU Charter in Case C-540/03, European Parliament v. Council, decided 27 June 2006. While not legally binding itself, the Charter reaffirms rights which are legally binding due to their provenance from other sources which are recognised by Community law as legally binding sources, including "international obligations common to the Member States", of which ILO Conventions are a prime example. In Case C438/05, Viking, Advocate General Maduro concluded: “...the rights to associate and to collective action are of a fundamental character within the Community legal order, as the Charter of Fundamental Rights of the European Union reaffirms". In Case C341/05, Laval, Advocate General Mengozzi, cites Article 28 of the EU Charter and concludes that "the right to resort to collective action to defend trade union members' interests is a fundamental right. It is... a general principle of Community law, within the meaning of Article 6(2) EU. That right must therefore be protected in the Community".

Two examples to illustrate the use of ILO standards in EU secondary legislation: the Directives on public procurement, and the Services Directive.

On the matter of substance, the potential use of ILO standards as sources of EU law may be illustrated two recent developments in the USA and Canada.

In the USA, an agreement was reached in May 2007 between the administration of President George Bush and the Congress on bilateral trade agreements to include the 
obligations of the ILO's 1998 Declaration on the Fundamental Principles and Rights at Work.

In Canada, on 8 June 2007 the Supreme Court of Canada declared that the protection of the freedom of association guaranteed by section 2(d) of the Canadian Charter of Rights and Freedoms includes a procedural right to collective bargaining. It held that "collective bargaining is an integral component of freedom of association in international law, which may inform the interpretation of Charter guarantees". It cites ILO Convention No. 87, ratified by Canada, as a principle that Canada has committed itself to uphold". It also cites interpretations by the ILO's Committee on Freedom of Association, Committee of Experts and Commissions of Inquiry

Freedom of association in trade unions has acquired constitutional status in some Member States. In interpreting the right at EU level, the ECJ could draw upon a range of sources, including international law, in particular, ILO Conventions, consistent with the evolving context of the EU from a purely economic Community establishing a common market to a European Union with a social policy aimed at protecting workers employed in the common market who are also citizens of the Union enjoying fundamental rights. The acquis communautaire social comprises five principles of what may be called ordre communautaire social: (i) the ILO principle that "labour is not a commodity"; (ii) the Community's social policy of improved living and working conditions; (iii) respect for fundamental rights of workers; (iv) a central role to social dialogue at EU and national levels; (v) equal treatment of all workers without discrimination based on nationality.

Fundamental rights of labour in the EU legal order are at stake in Laval and Viking. The Opinions of the Advocates General in these cases propose different solutions. The ECJ may accommodate these approaches in a solution consistent with ILO standards comprising the following five steps.

- In Viking, Advocate General Maduro takes the position that in cases of relocation, collective action is permitted to combat social dumping provided it is taken before the relocation occurs.

- Relocation is almost invariably accompanied by collective dismissals of workers. The ECJ in Case C-188/03, Junk, declared unequivocally that any decision to collectively dismiss workers can only be taken after the completion of the process of information and consultation.

- Relocation between Member States will often be the action of multinational enterprises. European works councils (EWCs) have successfully taken legal action to block decisions by multinationals where the enterprise failed to comply with the requirements of the EWCs directive.

- The conclusion is that collective action should always be possible as any decisions affecting the workforce cannot be taken until the information and consultation requirements have been complied with. 
- For Advocate General Mengozzi in Laval, the criterion is proportionality. The criterion of proportionality should be whether the employer had complied with the EU obligation to inform and consult prior to any decision. Failure to do so would automatically make any resulting collective action proportionate.

This is a specifically EU criterion of proportionality based on the acquis communautaire of EU Directives requiring information and consultation, Article 27 of the EU Charter (the fundamental right to information and consultation) and the transnational nature of enterprises and of collective action in the EU. If complied with, it contributes to avoiding the negative consequences of both litigation (seeking remedies in the form of injunctions from national courts to enforce the obligation to inform and consult) and collective industrial action by workers. It is a solution which reconciles respect for the international labour law standards of the ILO with the specific context of the acquis communautaire social.

The ECJ's jurisdiction in labour law offers the prospect of consolidating the EU as a major player in the emerging legal order of globalisation. The EU Charter's labour rights may become a model for international labour law.

\section{Introduction: The questions to be addressed}

The scope and substance of the jurisdiction of the European Court of Justice (ECJ) in the field of labour law depends on the sources of law available to it to use. This paper addresses two questions.

First, as to scope: do the sources of the ECJ's jurisdiction on labour law allow for consideration of ILO standards, and have the sources of law available and used in the past changed so as to embrace ILO standards?

Secondly, as to substance: is the nature of the labour law of the ILO compatible with the use to which it may be put in the context of the EU and its labour law, and are there changes elsewhere in the world which indicate a greater role for ILO standards in the labour law jurisdiction of the ECJ?

During and after providing some outline answers to these questions, I will seek to illustrate them by reference to two cases currently before the ECJ: Viking ${ }^{1}$ and Laval. ${ }^{2}$

The basic issue is: how much does, or will, the ECJ in exercising its jurisdiction in the field of labour law look to international standards, and how far does, or will, the ECJ seek to deviate from them, either by going further or by providing less?

1 Case C-438/05, Viking Line Abp OU Viking Line Eesti v. The International Transport Workers' Federation, The Finnish Seamen's Union, Opinion of Advocate General Maduro, 23 May 2007.

2 Case C-341/05, Laval un Partneri Ltd v. Svenska Byggnadsarbetareforbundet, Svenska Byggnadsarbetareforbundet, Avdelning 1, Svenska Elektrikerforbundet, Opinion of Advocate General Mengozzi, 23 May 2007. 


\section{Scope: The sources of the ECJ's jurisdiction in the field of labour law}

The sources from which the ECJ has drawn in exercising its labour law jurisdiction include the Treaties, EU secondary legislation and the general principles of the EU legal order.

\section{Treaties}

The social and labour policy of the European Economic Community as laid down in the Treaty of Rome of 1957 was influenced by ILO advisers. A preceding report of ILO experts 3 "recommended that there was no need for an interventionist social dimension for the proposed common market, save for certain measures against 'unfair competition'". 4 The result was Article 117 of the Treaty of Rome 1957.5 Far from looking to established international labour standards, in apparent order of priority, the desired improvement was to ensue from harmonisation of Member States' social systems, to result from both autonomous functioning of the common market and approximation of legal provisions.

Nonetheless, there was also room for the activation of "procedures provided for in this Treaty". Article 118 of the Treaty stated that the Commission "shall have the task of promoting close cooperation between Member States in the social field, particularly in matters related to... labour law and working conditions". However, initiatives by the Commission and the European Parliament encountered resistance from several governments and "it was not until 1971 that proposals began to emerge for a more systematic approach to European social policy". 6

The breakthrough came at the summit of the Heads of the Member States in Paris in October 1972, which in turn led the Commission to prepare a Social Action Programme

3 Report of the ILO's Committee of Experts (the 'Ohlin Report') on the Social Aspects of European Economic Cooperation, ILO Studies and Reports (New Series) No 46,1956; summarised in (1956) 74 International Labour Review 99. See generally, P. Davies . "The Emergence of European Labour Law", in W. McCarthy (ed), Legal Intervention in Industrial Relations: Gains and Losses, Blackwell, London, 1993, pp. 313-59; J. Kenner, EU Employment Law: From Rome to Amsterdam and beyond, Hart, Oxford, 2003, pp. 2-6.

4 B. Bercusson, European Labour Law, Butterworths, London, 1996, p. 48.

5 "Member States agree upon the need to promote improved working conditions and an improved standard of living for workers, so as to make possible their harmonisation while the improvement is being maintained. They believe that such a development will ensue not only from the functioning of the common market, which will favour the harmonisation of social systems, but also from the procedures provided for in this Treaty and from the approximation of provisions laid down by law, regulation or administrative action".

6 L. Wallyn, Social Europe, 1/87, pp.13-14. See also L.H.J. Crijns, "The social policy of the European Community", Social Europe 1/88, p. 51. 
duly adopted by the Council of Ministers on 21 January $1974 .{ }^{7}$ The European Court of Justice was not slow to follow with its famous judgment in Defrenne v. Sabena of 8 April 1976, proclaiming the double aim of Article 119 on equal pay for men and women: 8

“...this provision forms part of the social objectives of the Community, which is not merely an economic union, but is at the same time intended, by common action, to ensure social progress and seek the constant improvement of the living and working conditions of their peoples, as is emphasised by the Preamble to the Treaty".

The distance from international labour standards, if not explicitly those of the ILO, was narrowed by the Preamble of the Single European Act of 1986, which declared that the Community was:

"Determined to work together to promote democracy on the basis of the fundamental rights recognized in the constitutions and laws of the Member States, in the Convention for the Protection of Human Rights and Fundamental Freedoms [ECHR] and the European Social Charter [ESC], notably freedom, equality and social justice".

A first link to the ILO was established in the Preamble to the Community Charter of the Fundamental Social Rights of Workers of 1989, which declared: "Whereas inspiration should be drawn from the Conventions of the International Labour Organisation and from the European Social Charter of the Council of Europe". 9 Despite the nonlegally binding nature of the Community Charter, the Commission's Social Action Programme of 1989 explicitly relied on its provisions for a series of legislative and social policy proposals during the 1990s.

The Social Protocol to the Treaty on European Union of 1991 provided the legal basis for extensive labour law competences of the European Community. However, the explicit reference to fundamental rights in Article 6(2) of the Treaty on European Union referred only to the ECHR, and not the ESC, let alone the ILO. 10

The amendment of Article 117 EC (re-numbered Article 136) by the Treaty of Amsterdam 1997 compensated for this omission by providing:

"The Community and the Member States, having in mind fundamental social rights such as those set out in the European Social Charter signed at Turin on 18 October 1961 and in the 1989 Community Charter of the Fundamental Social Rights of Workers, shall have as their [social] objectives..."

Finally, the Preamble to the EU Charter of Fundamental Rights proclaimed at Nice in December 2000 reaffirms:

7 See Bercusson, European Labour Law, 1996, Chapter 4, pp. 49-64.

8 Case 43/75, Defrenne v. Société Anonyme Belge de Navigation Arienne (SABENA) [1976] ECR 455, paragraph 10.

9 For a discussion of the debates preceding the Charter and its relation to ILO standards, see B. Bercusson, "Fundamental Social and Economic Rights in the European Community", in A. Cassese, A Clapham and J. Weiler (eds), Human Rights and the European Community: Methods of Protection, Nomos, Baden-Baden 1991, pp. 195-290, at pp. 257-262.

10 Article 6(2) TEU: "The Union shall respect fundamental rights, as guaranteed by the European Convention for the Protection of Human Rights and Fundamental Freedoms signed in Rome on 4 November 1950 and as they result from the constitutional traditions common to the Member States, as general principles of Community law". 
“...rights as they result, in particular, from the... international obligations common to the Member States, the European Convention for the Protection of Human Rights and Fundamental Freedoms, the Social Charters adopted by the Union and by the Council of Europe and the case law of the Court of Justice of the European Union and of the European Court of Human Rights".

The absence of an explicit reference in the EU Charter to ILO labour standards is notable. 11

\section{General principles of the EU legal order}

The significance of the reference in the EU Charter's Preamble to "international obligations common to the Member States" is clear. ILO Conventions ratified by all Member States are recognised as a source of law underpinning the rights proclaimed. In fact, this merely reflects a longstanding position taken by the ECJ in Nold: 12

"As the Court has already stated, fundamental rights form an integral part of the general principles of law, the observance of which it ensures. Safeguarding these rights, the Court is bound to draw inspiration from constitutional traditions common to the Member States... Similarly, international treaties for the protection of human rights on which the Member States have collaborated or of which they are signatories, can supply guidelines which should be followed within the framework of Community law".

11 It was highlighted by the addition by the Convention on the Future of Europe of a further sentence to this paragraph of the Preamble: "In this context, the Charter will be interpreted by the Courts of the Union and the Member States with due regard for the explanations...". The "explanations" referred to were originally prepared by the Praesidium of the Convention which drafted the Charter, but this was done on its own responsibility and the "explanations" were explicitly declared to have no legal value. This additional sentence purported to ascribe some legal value to the explanations. See also the additional Article 52(7) added to the Charter by the IGC in June 2004: "The explanations drawn up as a way of providing guidance in the interpretation of the Charter of Fundamental Rights shall be given due regard by the courts of the Union and of the Member States". This provision makes use by the courts of the Praesidium's explanations more difficult because the Praesidium's explanations are not always comprehensive or consistent in referring to, for example, those "international obligations common to the Member States" which are explicitly the interpretative context, the inspiration and source of the EU Charter's provisions. The explanations, as "updated" by the Member States at the IGC of June 2004, include 22 references to the European Social Charter and Revised European Social Charter and 15 references to the Community Charter of the Fundamental Social Rights of Workers. See Provisional consolidated version of the Declarations to be annexed to the Final Act of the Intergovernmental Conference, CIG 86/04, ADD 2, Brussels, 25 June 2004. Now in OJ C310 of 16 December 2004, at p. 424. For a detailed exposition of the "updated" revisions to the Explanations, see Appendix 2 in B. Bercusson (ed), European Labour Law and the EU Charter of Fundamental Rights, Nomos, Baden-Baden, 2006, pp. 533-632. In particular, in the case of those provisions referring to individual employment and collective labour rights, the absence in the Praesidium's explanations of references to the core ILO Conventions which bind all Member States is noticeable, and regrettable. For examples illustrating this point, see B. Bercusson, "Postscript: The EU Charter of Fundamental Rights and the Constitution of the European Union", in B. Bercusson (ed), European Labour Law and the EU Charter of Fundamental Rights, pp. 455-530, at pp. 498-501.

12 Case 4/73, Nold v. Commission, [1974] ECR 491, paragraph 13. 
Since its proclamation on 7 December 2000, every Advocate General has cited the Charter in one or more Opinions, as has the Court of First Instance in a number of judgments. ${ }^{13}$ The first judicial reference to the EU Charter was made by the Court of First Instance in a decision of 30 January $2002 .{ }^{14}$ Five and half years after its proclamation, the ECJ itself finally cited the EU Charter in Case C-540/03, European Parliament v. Council, decided 27 June 2006. ${ }^{15}$. The Court states: 16

"The Charter was solemnly proclaimed by the Parliament, the Council and the Commission in Nice on 7 December 2000. While the Charter is not a legally binding instrument, the Community legislature did, however, acknowledge its importance by stating, in the second recital in the preamble to the Directive, that the Directive observes the principles recognised not only by Article 8 of the ECHR but also in the Charter. Furthermore, the principal aim of the Charter, as is apparent from its preamble is to reaffirm 'rights as they result, in particular, from the constitutional traditions and international obligations common to the Member States, the Treaty on European Union, the Community Treaties, the [ECHR], the Social Charters adopted by the Community and by the Council of Europe and the case-law of the Court... and of the European Court of Human Rights"'.

In other words, while not legally binding itself, the Charter reaffirms rights which are legally binding due to their provenance from other sources which are recognised by Community law as legally binding sources. ${ }^{17}$ These sources include "international obligations common to the Member States", of which ILO Conventions are a prime example.

13 In the first 30 months of its existence, up to July 2003, there were 44 citations of the Charter before the European courts. For details of these 44 cases, see Appendix 3, prepared by Stefan Clauwaert and Isabelle Schömann, in B. Bercusson (ed), European Labour Law and the EU Charter of Fundamental Rights, Nomos, Baden-Baden, 2006, pp. 633-714.

14 Case T-54/99, max.mobil Telekommunikation Service GmbH v. Commission, [2002] ECR II-313, paragraphs 48 and 57.

15 Case C-540/03. In a second case, Unibet, Case C-432/05, decided 13 March 2007, the Grand Chambre of the Court stated (paragraph 37) that "the principle of effective judicial protection is a general principle of Community law stemming from the constitutional traditions common to the Member States,... and which has also been reaffirmed by Article 47 of the Charter of fundamental rights of the European Union, proclaimed on 7 December 2000 in Nice (OJ 2000 C 364, p. 1)". A third reference by the Court to the Charter is in Case C-303/05 Advocaten voor de Wereld VZW, decided 3 May 2007, paragraph 46. For an exploration of the potential role of the ECJ in developing a "social constitution" for the EU using the EU Charter, see the chapter by Bruno Veneziani and Niklas Bruun in B. Bercusson (ed), Manifesto for a Social Constitution: 8 options for the European Union, ETUI, Brussels, May 2007.

16 Case C-540/03, paragraph 38. The key text in the judgment is under the rubric "Findings of the Court" (beginning paragraph 35) with regard to the issue "The rules of law in whose light the Directive's legality may be reviewed" (beginning paragraph 30 ).

17 See also the following statement in the Opinion of Advocate General Kokott in Case C-540/03: (paragraph 108) "While the Charter still does not produce binding legal effects comparable to primary law, it does, as a material legal source, shed light on the fundamental rights which are protected by the Community legal order." 


\section{An illustration: Collective industrial action}

The force of fundamental rights derived from international obligations common to the Member States can be illustrated in two cases currently pending before the ECJ.

In Viking, the defendant trade unions "point out that the right of association and the right to strike are protected as a fundamental right in various international instruments". ${ }^{18}$ To the proposition that there exists a fundamental right to collective action there were varying degrees of assent in the submissions of the Member States in the case. 19 The Commission representative's oral submission cited the ECHR, Article 11, ILO Conventions, the European Social Charter and the EU Charter, Article 28. The Commission's representative concluded: the right to collective action seems in principle to be part of the general principle of EU law that protects fundamental rights. Member States have a wide margin of appreciation. But EU law precludes measures which deny the essence of the fundamental rights protected. ${ }^{20}$ Advocate General Maduro concluded: 21

"...the rights to associate and to collective action are of a fundamental character within the Community legal order, as the Charter of Fundamental Rights of the European Union reaffirms".

In Laval, the submission that the right to take collective industrial action falls outside the scope of Community law by virtue of Article 137(5) EC 22 was firmly rejected by Advocate General Mengozzi. ${ }^{23} \mathrm{He}$ cites Article 6(2) TEU requiring the Union to re-

18 Case C-438/05, Viking Line Abp OU Viking Line Eesti v. The International Transport Workers' Federation, The Finnish Seamen's Union, Opinion of Advocate General Maduro, 23 May 2007, para. 20.

19 Some were explicit: Austria, Belgium, Finland, France, Germany, Ireland, Italy, Norway and Sweden. Others were implicit: although they denied the protection afforded by the right in this case, there was confirmation that such a fundamental social right did exist: the Czech Republic, Denmark, Estonia, Latvia, Poland. The only unequivocal assertion that there was no fundamental right to take collective action in Community law came from the UK.

20 Notes made by the author at the oral hearing before the ECJ in Luxembourg on 10 January 2007. For a detailed analysis, see B. Bercusson, "The Trade Union Movement and the European Union: Judgment Day", (2007) 13 European Law Journal (No. 3, May), pp. 279-308 at pp. 298-302.

21 Viking, para. 60, citing Articles 12 and 28 of the EU Charter. In earlier writings, Maduro referred to "a hard core of social rights" which includes "the rights to collective action and collective bargaining". He stated: 'The right to collective bargaining, the freedom of association, the right to collective action ["rights immediately effective and judicially enforceable"]... should be considered as part of the "constitutional traditions common to the Member States"'. M. Poiares Maduro, 'Striking the Elusive Balance Between Economic Freedom and Social Rights in the EU', in P. Alston (ed), The EU and Human Rights (Oxford University Press, 1999), pp. 449-472, at p. 461. There follows a footnote 51 in which Maduro refers to the Community Charter of the Fundamental Social Rights of Workers of 1989, and 'for a recent international example, including some of the rights which it has been argued constitute fundamental social rights: the ILO Declaration on Fundamental Principles and Rights at Work, approved at the 86th Session, Geneva, June 1998'.

22 Article 137(5) EC: "The provisions of this Article shall not apply to pay, the right of association, the right to strike or the right to impose lock-outs".

23 Case C-341/05, Laval un Partneri Ltd v. Svenska Byggnadsarbetareforbundet, Svenska Byggnadsarbetareforbundet, Avdelning 1, Svenska Elektrikerforbundet, Opinion of Advocate General Men- 
spect fundamental rights, notes that it mentions only the ECHR and also the ECJ's view that the ECHR has special significance to enable the Court to identify the general principles of Community law. ${ }^{24}$ Crucially, he adds: 25

"The Court is entitled, in so doing, to draw inspiration from instruments for the protection of human rights other than the ECHR".

He goes on to cite the references in the Preamble to the EU Treaty and in Article 136

EC to the European Social Charter and the 1989 Community Charter. ${ }^{26}$ He continues: 27

"The Court's concern to accord 'special significance' to the ECHR, without thereby excluding other sources of inspiration, found expression in the Charter of Fundamental Rights of the European Union solemnly proclaimed on 7 December $2000 \ldots$

Admittedly, the Charter of Fundamental Rights is not a legally binding instrument. However, the Court has already emphasised that its principal aim, as is apparent from its preamble, is to 'reaffirm rights as they result, in particular, from the constitutional traditions and international obligations common to the Member States...".

He subsequently analyses the limited protection for the right to strike available under the ECHR, but goes on to cite Article 6(4) of the European Social Charter, which explicitly recognises the right to strike, as does paragraph 13 of the 1989 Community Charter, Article 28 of the EU Charter and the constitutional instruments of numerous Member States. ${ }^{28}$ His conclusion is:

"This analysis prompts me to consider that the right to resort to collective action to defend trade union members' interests is a fundamental right. ${ }^{29}$ It is therefore not merely a 'general principle of labour law', as the Court has already held in relatively old case-law in Community staff cases, but rather a general principle of Community law, within the meaning of Article 6(2) EU. That right must therefore be protected in the Community".

gozzi, 23 May 2007, paras. 48 ff. For the same conclusion, see B. Bercusson, Commentary on Article 12 of the EU Charter, Freedom of assembly and of association, chapter 6 in B. Bercusson (ed), European Labour Law and the EU Charter of Fundamental Rights, Nomos, Baden-Baden, 2006, pp. 133-169, at pp.163-164, and earlier in B. Bercusson, European Labour Law, Butterworths, London, 1996, at p. 546-548.

24 Ibid., paras. 63-64.

25 Ibid., para. 65 (italics added).

26 Ibid., para. 66.

27 Ibid., paras. 67-68 (italics added).

28 Ibid., paras. 69-77. Footnote 33 cites the Constitutions of Bulgaria, Cyprus, Estonia, France, Greece, Hungary, Italy, Latvia. Lithuania, Poland, Portugal, Romania, Slovakia, and Slovenia.

29 Citing para. 159 of the Opinion of Advocate General Jacobs in Albany International BV v. Stichting Bedrijfspensioenfonds Textielindustrie, Case C-67/96; with Joined cases C-115/97, C-116/97 and C117/97; [1999] ECR I-5751: "In my view, the right to take collective action in order to protect occupational interests in so far as it is indispensable for the enjoyment of freedom of association is also protected by Community law". In Albany, the Commission cited, inter alia, ILO Conventions Nos 87 and 98 in support of their contention that the right to collective bargaining is a fundamental right. This contention was not accepted by Advocate General Jacobs; see paras. 141-142. 


\section{EU secondary legislation}

Two examples will be invoked to illustrate the use of ILO standards in EU secondary legislation: the Directives on public procurement, and the Services Directive.

\section{a) Public procurement}

New EU Directives on public procurement ${ }^{30}$ were to be implemented into national law by $31^{\text {st }}$ January 2006 . The outcome of the legislative process was less than satisfactory, as the process of revision led to a stalemate between those who wished to exclude social and labour standards, and those who wished them to be mandatory or at least optional. In the end, the status quo was resoundingly affirmed: the EU Directives are intended to reflect the position of the European Court of Justice. ${ }^{31}$ The problem is that the precise nature of this status quo is hotly disputed. ${ }^{32}$

Recital 33 of the Preamble to the Directive states:

"Contract performance conditions are compatible with this Directive provided that they are not directly or indirectly discriminatory and are indicated in the contract notice or in the contract documents... For instance, mention may be made, amongst other things, of the requirements - applicable during performance of the contract - ...to comply in substance with the provisions of the basic ILO Conventions, assuming that such provisions have not been implemented in national law...".

30 Directive 2004/17/EC of the European Parliament and of the Council of 31 March 2004 coordinating the procurement procedures of entities operating in the water, energy, transport and postal services sectors, OJ L134/1 of 30 April 2004; Directive 2004/18/EC of the European Parliament and of the Council of 31 March 2004 on the coordination of procedures for the award of public works contract, public supplies contracts and public service contracts, OJ L134/114 of 30 April 2004.

31 Recital 1 of the Preamble to Directive 2004/18/EC: "This Directive is based on Court of Justice case-law, in particular case-law on award criteria, which clarifies the possibilities for the contracting authorities to meet the needs of the public concerned, including in the environmental and/or social area, provided that such criteria are linked to the subject-matter of the contract, do not confer an unrestricted freedom of choice on the contracting authority, are expressly mentioned and comply with the fundamental principles mentioned in recital 2."

32 For example, a Commission Working Document of 3 April 2001 prepared by the Internal Market Directorate General deals with "Interpretation of Community public procurement law and the possibilities for incorporating social considerations in public procurement". Document CC/01/10 EN, Brussels, 3 April 2001, MARKT/B2/NSK. The last paragraph on page 8 says that to require public procurement contractors to comply with ILO Conventions (footnote 22: child labour, freedom of association, etc.), these "must previously have been ratified by a given country and, where necessary, have been incorporated into their national law". No authority is provided for this statement. The document continues: "Most of these Conventions concern the respect of fundamental economic and social rights which have already been implemented in social and other legislation, and are therefore applicable in any event". It is not clear that EC law on public procurement requires that ILO Conventions must they have been ratified or incorporated. So long as the fundamental economic and social rights in these Conventions are applied on a transparent and non-discriminatory basis by the contracting authority, it does not matter if the Member State has ratified or incorporated them. 
ILO Convention 94, the Labour Clauses (Public Contracts) Convention 1949, requires compliance with labour standards going beyond anything envisaged by current directives. The ILO Convention requires contracts to include clauses ensuring working conditions, including those in collective agreements. ${ }^{33}$ The ILO Convention has been ratified by nine Member States (one of which, the UK, denounced it in 1982). The ratifying Member States are: Austria, Finland, France (1951), Belgium, Italy, Netherlands (1952), Denmark (1955) and Spain (1971). ${ }^{34}$

The implication is that ILO Convention No. 94 is consistent with EC law, including the procurement directives. If the Convention is consistent with EC law, there can be no objection in EC law to incorporating similar clauses in the current revision of the directives. Eight Member States clearly support such a policy by continuing their ratification of the Convention.

The issue is about to come before the ECJ in Case C-346/06, Dirk Rüffert v. Land Niedersachsen. ${ }^{35}$ The question referred to the ECJ is: "Does it amount to an unjustified restriction on the freedom to provide services under the EC Treaty if a public contracting authority is required by statute to award contracts for building services only to undertakings which, when lodging a tender, undertake in writing to pay their employees, when performing those services, at least the remuneration prescribed by the collective agreement in force at the place where those services are performed?"

The overlap between Viking/Laval and Rüffert is obvious. They involve enterprises moving from one Member State to provide services in another Member State. In this context the fact that the EU has recently adopted, after three years of contentious debate, the Directive on Services, should not be ignored.

33 In the Commission Working Document of 3 April 2001 cited in the previous footnote, D.-G. XV accepts that "A contracting authority may impose on the party to whom a contract is awarded labour clauses such as those mentioned in ILO Convention No. 94, provided that they respect the relevant provisions of Community law...". The very wide scope of the clauses covered in the ILO Convention No. 94 is acknowledged in footnote 25 of the document. D.-G. XV's acquiescence that such clauses, including provisions of collective agreements, can be made obligatory in public procurement raises questions about the extreme caution regarding the compatibility of social clauses with EC law which is manifest in the rest of the interpretation document. Unless the caveat: " provided that they respect the relevant provisions of Community law", is regarded as withdrawing much of D.-G. XV's apparent acceptance of this Convention.

34 Article 307 EC allows Member States to continue to be bound by international treaties unless they contravene their EC law obligations, in which case they are obliged to denounce those Treaty obligations. See the case of ILO Conventions prohibiting night work for women: Case C-345/89 Criminal Proceedings against Alfred Stoeckel [1991] ECR I-4047; Case C-158/91, Levy [1993] ECR I-4287; Case C13/93 Office National de l'Emploi v. Madeleine Minne [1994] ECR I-371.

35 Referred 18 July 2006; notified 28 September 2006. 


\section{b) The Services Directive}

\section{Article 1(7) of the Services Directive ${ }^{36}$ provides:}

"This Directive does not affect the exercise of fundamental rights as recognised in the Member States and by Community law. ${ }^{37}$ Nor does it affect the right to negotiate, conclude and enforce collective agreements and to take industrial action in accordance with national law and practices which respect Community law".

There is clear acknowledgment in the first sentence that "fundamental rights... [are] recognised... by Community law". 38 The other rights referred to are arguably these specified in the second sentence (eiusdem generis): Community law protects "the right to negotiate, conclude and enforce collective agreements and to take industrial action in accordance with national law and practices which respect Community law".39

This is an interpretation consistent with Recital 15:

"This Directive respects the exercise of fundamental rights applicable in the Member States and as recognised in the Charter of fundamental Rights of the European Union and the accompanying explanations, reconciling them with the fundamental freedoms laid down in Articles 43 and 49 of the Treaty. Those fundamental rights include the right to take industrial action in accordance with national law and practices which respect Community law".

Recital 15's explicit reference to the EU Charter is significant. The reference to reconciliation with fundamental freedoms in Articles 43 and 49 may be read as confirming that, in particular, the right to take industrial action can be reconciled with Articles 43 and 49 - the point at stake in Viking and Laval. ${ }^{40}$

36 Directive 2006/123/EC of the European Parliament and of the Council of 12 December 2006 on services in the internal market, L 376/36 of 27.12.2006 (italics added).

37 The rights concerned are not the economic freedoms in Articles 43 and 49, since these are the legal basis of the Directive, which aims to supplement their inadequacies. See Recital 6.

38 Compare Council Regulation (EC) No. 2679/98 of 7 December 1998 on the functioning of the internal market in relation to the free movement of goods among the Member States. OJ L337/8 of 12.12.98; Article 2, which does not refer to fundamental rights recognised by Community law: "This Regulation may not be interpreted as affecting in any way the exercise of fundamental rights as recognised in Member States, including the right or freedom to strike. These rights may also include the right or freedom to take other actions covered by the specific industrial relations systems in Member States.“

39 Italics added. The second sentence (and, in particular, its last phrase: "which respect Community law") may be interpreted as meaning that insofar as national law and practices do not respect fundamental rights recognised by Community law they are affected by the Directive. The provisions of the Directive which will affect national law and practices on collective bargaining and action are the Directive's provisions which stipulate that rules laid down by collective agreements do not violate free movement provisions. I.e. if national rules were to stipulate that collective agreements or collective action contravene free movement rules, this would violate Community law's protection of these fundamental rights.

40 The position is further elaborated, if not clarified, by Recital 83, concerned with derogations from the freedom to provide services and exceptional measures against a given provider: "In addition, any restriction of the free movement of services should be permitted, by way of exception, only if it is consistent with fundamental rights which form an integral part of the general principles of law enshrined in the Community legal order". 


\section{Substance: The nature of ILO standards as sources of EU law}

International labour law has its most important source in the norms promulgated by the International Labour Organisation (ILO), established in 1919, which declared as one of its principles that "labour should not be regarded merely as a commodity or article of commerce". 41

In terms of their content, ILO norms have slowly but surely increased in number and scope and are now numerous and cover a huge range of topics. However, the standard of the norms adopted has often been minimal: the lowest common denominator. In terms of their adoption and enforcement, the tripartite principle of participation of representatives of employers and workers alongside governments has increased the likelihood of approval of norms by ILO institutions and enhanced their legitimacy. However, the mechanisms of enforcement of norms adopted have been acknowledged as often inadequate.

EC labour and social law does not strictly conform to this framework. Labour, and even more so social matters, were relatively marginal to the original objectives of the European Economic Community, founded in 1957 to establish a common market for goods, services, capital and labour. Despite the expansion of competences in labour law by the Social Protocol and Agreement on Social Policy of the Treaty of Maastricht, now incorporated into the EC Treaty, Article 137, in terms of their content, the development of norms regarding labour during almost five decades of existence of the EC has been spasmodic, episodic and unsystematic. Despite the great leap forward of the constitutionalisation of the European social dialogue by the Maastricht Treaty, now in Articles 138-139 EC, the combination of a Commission allergic to regulation and a blocking minority of Member States in the Council has led the social dialogue into its current impasse. However, the mechanisms of enforcement extend far beyond the possibilities available to the ILO machinery. These qualities of content and procedures of adoption and enforcement of norms are important to understanding the specificity of EC labour law.

The ILO singularly failed in its attempt to build on the corpus of international economic law to promote labour standards in an integrated global economy . The story of the failure of attempts to persuade the WTO to incorporate labour standards is well known. ${ }^{42}$ The endless debate over social dumping v. protectionism resulted in stalemate, or worse...

41 Article 427 of the Treaty of Versailles, 1919, which contained the first ILO Constitution. The Constitution was revised in 1944, and Article 1 declared its aims and purposes to be those of the Declaration annexed to the Constitution, which "reaffirms the fundamental principles on which the Organisation is based and, in particular, that - (a) labour is not a commodity". P. O'Higgins, "'Labour is not a commodity' - an Irish contribution to international labour law", (1997) 26 Industrial Law Journal.225.

42 See B.A. Hepple, Labour Laws and Global Trade, Hart, Oxford, 2005. 
The ECJ in its labour law jurisdiction is similarly confronted with vital issues of the rights of workers in a legal framework developed to promote the economic freedom of employers in a single European market. To what extent do the labour standards of the ILO offer a model? Two approaches are illustrated by very recent developments.

\section{The United States experience}

A minimal approach is illustrated by an agreement reached in May 2007 between the administration of President George Bush and the Congress on labour standards in bilateral trade agreements. ${ }^{43}$ The agreement incorporates the binding obligation that countries uphold in their laws and practice the obligations of the International Labour Organization's 1998 Declaration on the Fundamental Principles and Rights at Work. The relevant principles are the freedom of association, the effective recognition of the right to bargain collectively, the elimination of all forms of forced or compulsory labour, the effective abolition of child labour and the elimination of discrimination in respect to employment and occupation.

The ILO standards will be included in the text of treaties and enforced like any other provision, with no exceptions for the United States. In this case, however, the standards are not those in eight separate ILO Conventions, which the United States has never ratified. The United States was thereby insulated from a body of ILO case. At one level, the US Congress has taken a major step forwards as regard trade and labour standards. However, the US social model is far from that of the EC and its acquis communautaire social.

\section{The Canadian experience}

Another approach, in my view more appropriate, is that illustrated by an even more recent development in Canada.

On 8 June 2007 the Supreme Court of Canada, reversing both the trial court and the British Columbia Court of Appeal, decided ${ }^{44}$ by a 6-1 majority that earlier decisions of the Supreme Court for the exclusion of collective bargaining from the protection of the freedom of association guaranteed by section 2(d) of the Canadian Charter of Rights and Freedoms ${ }^{45}$ did not withstand principled scrutiny and should be rejected. The Su-

43 See the Financial Times, 14 May 2007.

44 Health Services and Support - Facilities Subsector Bargaining Assn. v. British Columbia, 2007 SCC 27.

45 Canadian Charter of Rights and Freedoms, Article 2: "Everyone has the following fundamental freedoms:...(d) freedom of association [liberté d'association]". 
preme Court declared that freedom of association guaranteed by section 2(d) of the Charter includes a procedural right to collective bargaining: 46

"Our conclusion that s. 2(d) of the Charter protects a process of collective bargaining rests on four propositions. First, a review of the s. 2(d) jurisprudence of this Court reveals that the reasons evoked in the past for holding that the guarantee of freedom of association does not extend to collective bargaining can no longer stand. Second, an interpretation of s. 2(d) that precludes collective bargaining from its ambit is inconsistent with Canada's historic recognition of the importance of collective bargaining to freedom of association. Third, collective bargaining is an integral component of freedom of association in international law, which may inform the interpretation of Charter guarantees. Finally, interpreting s. 2(d) as including a right to collective bargaining is consistent with, and indeed, promotes, other Charter rights, freedoms and values."

Each of these propositions could usefully be explored for its applicability to the EU context. ${ }^{47}$ However, it is the third proposition, that "collective bargaining is an integral component of freedom of association in international law, which may inform the interpretation of Charter guarantees" which is of most interest in this paper.

In the section of the judgment entitled "International Law Protects Collective Bargaining as Part of Freedom of Association" 48 , the Supreme Court confirms that "Canada's international obligations can assist courts charged with interpreting the Charter's guarantees". 49 The Supreme Court states that "the Charter should be presumed to provide at least as great a level of protection as is found in the international human rights documents that Canada has ratified". 50

The Court cites as "sources most important to the understanding of s. 2(d) of the Charter" the International Covenant on Economic, Social and Cultural Rights, (ICESCR), the International Covenant on Civil and Political Rights (ICCPR), and the ILO's Convention No. 87 Concerning Freedom of Association and Protection of the Right to Organize. As "Canada has endorsed all three of these documents... ratifying Convention No. 87 in 1972. this means that these documents reflect not only interna-

46 Para. 20 of the judgment.

47 For example, the third proposition: "an interpretation of [freedom of association] that precludes collective bargaining from its ambit is inconsistent with [the EU Member States'] historic recognition of the important of collective bargaining to freedom of association". See B. Bercusson and N. Bruun, "Overview" (pp. 2-50) to the European Industrial Relations Dictionary, published by the European Foundation for the Improvement of Living and Working Conditions, Luxembourg: Office for Official Publications of the European Communities, 2005, especially pp. 4-11. For further discussion, see below. On interpretation of Article 12 ("Freedom of assembly and of association") of the EU Charter of Fundamental Rights, see the commentary in B. Bercusson (ed), European Labour Law and the EU Charter of Fundamental Rights, Nomos, Baden-Baden, 2006, pp. 133-169. The EU Charter, of course, not only protects freedom of association, it explicitly protects the right of collective bargaining and action (Article 28). For commentary on Article 28, see B. Veneziani in Bercusson (ed), op. cit., pp. 291-336.

48 Paras. 69-79.

49 Para. 69.

50 Para. 70. 
tional consensus, but also principles that Canada has committed itself to uphold". 51 The Supreme Court continues: 52

"The ICESCR, the ICCPR and Convention No. 87 extend protection to the functioning of trade unions in a manner suggesting that a right to collective bargaining is part of freedom of association. The interpretation of these conventions, in Canada and internationally, not only supports the proposition that there is a right to collective bargaining in international law, but also suggests that such a right should be recognized in the Canadian context under s. 2(d)".

Specifically as regards the ILO Convention, the Supreme Court states: 53

"Convention No. 87 has been the subject of numerous interpretations by the ILO's Committee on Freedom of Association, Committee of Experts and Commissions of Inquiry. These interpretations have been described as the 'cornerstone of the international law on trade union freedom and collective bargaining': M. Forde, 'The European Convention on Human Rights and Labor Law', (1973) 31 Am. J. Comp. L. 301 at 203. While not binding, they shed light on the scope of s. 2(d) of the Charter as it was intended to apply to collective bargaining...”.

The Supreme Court then goes on the quote at length a recent review by ILO staff summarizing a number of principles concerning collective bargaining. 54

In this connection, it is worth noting the Supreme Court's careful reference to the fact that "that the present case does not concern the right to strike, which was considered in earlier litigation on the scope of the guaranteed of freedom of association". 55 Had the case concerned the right to strike, the question would have arisen whether international law protects the right to strike as part of freedom of association.

Although there is no express recognition of the right to strike in ILO Convention 87, it has been implied into Convention 87 , Article 3, by the supervisory bodies. According to the ILO Committee of Experts: "The right to strike is one of the essential means through which workers and their organisations may promote and defend their economic and social interests". The jurisprudence of the supervisory bodies on the nature and scope of the right to strike is now extensive. It is more than coincidental that an account is provided by the same three officials of the ILO cited by the Supreme Court in an earlier article. 56 According to Gernigon et al., since 1952 the Freedom of Association Committee has recognised "the right to strike to be one of the principal means by which

51 Para. 71.

52 Para. 72.

53 Para. 76.

54 B. Gernigon, A. Odero and H. Guido, "ILO principles concerning collective bargaining" (2000) 139 International Labour Review 33, at pp. 51-52. The Supreme Court goes on to add: (para. 78) "The fact that a global consensus on the meaning of freedom of association did not crystallize in the Declaration on Fundamental Principles and Rights at Work... until 1998 does not detract from its usefulness in interpreting s. 2(d) of the Charter". One of the principles listed by Gernigon et al.., "the principle of good faith in collective bargaining" is further emphasised in para. 98 of the judgment.

55 Para. 19.

56 B. Gernigon, A. Odero and H. Guido, "ILO Principles Concerning the Right to Strike" (1998) 137 International Labour Review 441-481. There is also a fuller account in ILO, Freedom of Association - Digest of Decisions and Principles of the Freedom of Association Committee of the Governing Body of the ILO (4 $4^{\text {th }}$ ed, 1996). 
workers and their associations may legitimately promote and defend their economic and social interests". 57

So far as secondary boycotts are concerned, this is an issue where the supervisory bodies have gradually accepted that the conduct in question is protected by Convention 87 as an incident of the right to strike. The Committee of Experts addressed this matter in 1994 in the following terms:

"Sympathy strikes, which are recognised as lawful in some countries, are becoming increasingly frequent because of the move towards the concentration of enterprises, the globalisation of the economy and the delocalisation of work centres. While pointing out that a number of distinctions need to be drawn here (such as an exact definition of the concept of sympathy strike; a relationship justifying recourse to this type of strike, etc), the Committee considers that a general prohibition on sympathy strikes could lead to abuse and that workers should be able to take such action, provided the initial strike they are supporting is itself lawful". 58

Gernigon et al. suggest that the Committee has made "no direct statement or indication relating to sympathy strikes...". The authors point out, nevertheless, that since 1983 the Committee has "determined that a general prohibition of sympathy strikes could lead to abuse and that workers should be able to take such action provided that the initial strike they are supporting is itself lawful". 59

57 They continue in the following terms: "Over the years, in line with this principle, the Committee on Freedom of Association has recognised that strike action is a right and not simply a social act, and has also: 1. made it clear it is a right which workers and their organisations (trade unions, federations and confederations) are entitled to enjoy; 2 . reduced the number of categories of workers who may be deprived of this right, as well as the legal restrictions on its exercise, which should not be excessive; 3 . linked the exercise of the right to strike to the objective of promoting and defending the economic and social interests of workers (which criterion excludes strikes of a purely political nature from the scope of international protection provided by the ILO, although the Committee makes no direct statement or indication regarding sympathy strikes other than that cannot be banned outright...; 4. stated that the legitimate exercise of the right to strike should not entail prejudicial penalties of any sort, which would imply acts of anti-union discrimination". Ibid., p. 443.

58 The Committee of Experts' jurisprudence on this issue has been developed specifically in the context of the supervision of the United Kingdom's compliance with Convention 87. The ILO Committee of Experts has commented unfavourably on British law since 1989 so far as it relates to the right to strike. One of the provisions subject to criticism by the Committee of Experts was the redefinition of a trade dispute in the Employment Act 1982 (now the Trade Union and Labour Relations (Consolidation) Act 1992, section 244). Secondary action is still banned in Great Britain, though the ban is a clear breach of international legal obligations. See K. Ewing, Britain and the ILO, $2^{\text {nd }}$ ed., Institute of Employment Rights, London. 1994.

59 For this purpose sympathy action would include secondary boycotts: a sympathy strike is defined generically to mean "where workers come out in support of another strike". Gernigon et al. also refer to a report of the Freedom of Association Committee in a complaint in 1987 where a legislative decree imposed restraints on sympathy action. Gernigon et al. report that: “....although several provisions contained in the Decree might be justified by the need to respect various procedures (notification of the strike to the labour authorities) or to guarantee security within the undertaking (the prevention of agitators and strike-breakers from entering the workplace) others, however, such as geographical or sectoral restrictions placed on sympathy strikes... or restrictions on their duration or frequency, constitute a serious obstacle to calling strikes". More recent cases deal with matters such as a complaint from Greece about restrictions on the right to strike by seafarers, and another from Australia involving a dispute on the waterfront. The latter is particularly important for highlighting 


\section{$V$. The current challenge: ordre communautaire social}

The ECJ's jurisdiction in labour law points to the need to identify the common traditions and legal and constitutional practices protecting fundamental social, labour and trade union rights in the laws of the Member States.

For example, freedom of association in trade unions has acquired constitutional status in some Member States. Sometimes this is a part of a constitutional guarantee of a general right of association, sometimes, the guarantee is granted by ordinary legislation or "basic agreements" between the social partners. Does a trade union's "right to freedom of association" also include other collective trade union rights, such as the right to collective bargaining and collective agreements, the right to strike or take other industrial action? Different Member State concepts of "freedom of association" include some, many or even all of these elements. 60

Trade union freedom of association includes some rights recognised in all (or most) Member States. In a Member State, a claim to the right of association in the EU Charter, as a question of EU law, could be referred by a national court to the ECJ under Article 234 of the EC Treaty. In interpreting the right at EU level, the ECJ could draw upon a range of sources, including international law, in particular, ILO Conventions, Council of Europe measures and existing EC law.

The ECJ's labour law jurisdiction cannot rely on the European Convention for the Protection of Human Rights (ECHR) of 1950. The ECHR is not focused on protection of the rights of workers. ${ }^{61}$ Social and labour rights are the focus of the European Social

the right of workers to seek international assistance and for confirming the protection for secondary action under ILO Convention 87.

60 Concepts of freedom of association often overlap; that does not mean they are the same. Different Member States will include some elements and exclude others. But there are elements of trade union rights which all, or most Member States agree are protected. These elements, on which there is consensus, can be assembled into a principle of "freedom of association" at EU level. A narrow formulation of "freedom of association" might include a large number of Member States where such a formulation is acceptable. The wider the range of rights, the lesser the number of Member States which accept that those rights are within the scope of the fundamental trade union right of freedom of association. The aim is a formulation which includes fundamental trade union rights recognised in all (or most) Member States: a common core of elements of a right of "freedom of association" which is shared by all, or a majority of the Member States. See B. Bercusson, Trade Union Rights in the 15 Member States of the European Union, Research Study for the Committee on Social Affairs and Employment, European Parliament, 1998; Summary (c. 45 pp.) translated and published in all EC languages.

61 In Case C-112/00, Eugen Schmidberger, Internationale Transporte und Planzuge v. Republic of Austria, [2003] ECR I-5659, the Court seemed willing to contemplate restrictions on freedom of expression or assembly, as allowed by the ECHR. In Case C-499/04, Hans Werhof v. Freeway Traffic Systems GmbH \& Co. KG, decided 9 March 2006, the ECJ cited the ECHR as protecting the negative right of association of employers not to be bound by collective agreements, but did not refer to the decision of the European Court of Human Rights in Wilson, NationalUnion of Journalists and Others v United Kingdom, judgment of 2 July 2002, Reports of Judgments and decisions 2002-V; [2002] Industrial Relations Law Reports 128 upholding the right of workers to freedom of associa- 
Charter (ESC) 1961 (revised in 1996).62 These rights have acquired constitutional status in some Member States. Though the ESC is within the category of the international treaties referred to in Nold, and, indeed, is explicitly referred to in Article 136 of the EC Treaty, ${ }^{63}$ the Court has not yet been willing to invoke the ESC as it does the ECHR. Moreover, ratification by all Member States (including the twelve recent accession States) of ILO Conventions No. 87 of 1948 (Freedom of Association and Protection of the Right to Organise) and No. 98 of 1949 (Application of the Principles of the Right to Organise and to Bargain Collectively) has produced a common foundation of trade union rights in all Member States.

The ECJ could play a role in constitutionalising the EU social model by adopting a specific interpretative framework for relevant provisions of the Treaties and secondary legislation. This interpretation would be consistent with the evolving context of the EU from a purely economic Community establishing a common market to a European Union with a social policy aimed at protecting workers employed in the common market who are also citizens of the Union enjoying fundamental rights. ${ }^{64}$

From the beginning of the European Community, improvement of living and working conditions was stipulated as a social policy objective. EU and Member State regulation of social provisions "shall have as their objectives the promotion of employment, improved living and working conditions, so as to make possible their harmonisation while the improvement is being maintained" (Article $136 \mathrm{EC}$ ).

Additionally, since the adoption of the new social policy provisions of the Treaty of Maastricht: "Should management and labour so desire, the dialogue between them at

tion as protecting their adhesion to collective agreements. See the critique in the Opinion of Advocate General Mengozzi in Laval, paras. 71-74.

62 All Member States (including the twelve recent accession States) have ratified either the 1961 or the 1996 Social Charters of the Council of Europe.

63 Article 136: "The Community and the Member States, having in mind fundamental social rights such as those set out in the European Social Charter signed at Turin on 18 October 1961 and in the 1989 Community Charter of the Fundamental Social Rights of Workers...".

64 The ECJ recognised the implications of this transformation for the nature of the EU in a case concerning the exclusion of part-time workers from supplementary occupational pension schemes. As formulated by the national court posing the question for the ECJ, the claim for a retrospective application of the principle of equal pay would risk distortion of competition and have a detrimental economic impact on employers. Nonetheless the Court concluded: ' ...it must be concluded that the economic aim pursued by Article 119 of the Treaty, namely the elimination of distortions of competition between undertakings established in different Member States, is secondary to the social aim pursued by the same provision, which constitutes the expression of a fundamental human right'. (Case C-50/96, Deutsche Telekom AG v Schroder [2000] ECR I-743, paragraph 57). Economic provisions of the Treaty have come to be re-interpreted in light of changes in the scope of activities of the EU. The ECJ's decision in Albany is another example of a case in which the Court acknowledged that the EC Treaty provisions on competition policy must be conditioned by other Treaty provisions on social policy; specifically, collective action in the form of collective bargaining/social dialogue. Albany International BV v. Stichting Bedrijfspensioenfonds Textielindustrie, Case C-67/96; with Joined cases C-115/97, C-116/97 and C-117/97; [1999] ECR I-5751. 
Community level may lead to contractual relations, including agreements" (Article 139(1) EC) and "Agreements concluded at Community level shall be implemented..." (Article 139(2) EC). Insofar as regulation of living and working conditions is left to social dialogue, the process of negotiation between the social partners, a crucial element in this process, is Treaty protected collective action.

This overriding interpretative framework comprises the accumulated body of EU social and labour law, the acquis communautaire social, including five principles of what may be called ordre communautaire social:

- universal premise of international labour law based on the Constitution of the ILO to which all Member States belong: "labour is not a commodity"; 65

- the activities of the Community shall include "a policy in the social sphere" (Article 3(1)(j) EC) and the Community and the Member States "shall have as their objectives... improved living and working conditions" (Article 136 EC);

- respect for fundamental rights of workers reflected in the Community Charter of the Fundamental Social Rights of Workers 1989, the European Social Charter signed at Turin on 19 October 1961 (both cited in Article 136 EC), and the EU Charter of Fundamental Rights solemnly proclaimed by the European Parliament, the European Council and the Commission at Nice on 7 December 2000;

- the distinctive characteristic of the European social model which attributes a central role to social dialogue at EU and national levels in the form of social partnership; 66

- the common market principle of equal treatment of all workers without discrimination based on nationality.

In brief, the ECJ is to interpret and apply EU in the light of ordre comunautaire social: labour is not a commodity like others (goods, capital), free movement is subject to the objective of improved working conditions, respecting the fundamental rights of workers as human beings, acknowledging the central role of social dialogue and social partnership at EU and national levels, and adhering to the strict principle of equal treatment without regard to nationality.

65 The Philadelphia Conference of 1944 adopted a Declaration defining the aims of the International Labour Organisation subsequently incorporated into the ILO Constitution which affirmed: „labour is not a commodity. “ The Preamble to the Community Charter of the Fundamental Social Rights of Workers of 1989 states: „Whereas inspiration should be drawn from the Conventions of the International Labour Organisation...".

66 See the "Overview" in B Bercusson and N Bruun, European Industrial Relations Dictionary, European Foundation for the Improvement of Living and Working Conditions, Luxembourg: Office for Official Publications of the European Communities, 2005, pp. 2-50, especially pp. 4-11. 


\section{ILO standards compatible with the acquis communautaire social}

In the immediate future, the ECJ is confronted with two cases, Laval and Viking, both for which raise in the most acute form the question of fundamental rights of labour in the EU legal order and related questions of respect by Member States of ILO standards. The Opinions of the Advocates General in these cases propose different solutions in balancing the economic freedoms of employers and the fundamental rights of workers and their organisations.

In Laval, Advocate General Mengozzi's assessment of the legitimacy of collective action is based on the criterion of "proportionality". This has obvious appeal for two reasons. It is a well-known criterion in EU law. It is also a way in which, as Advocate General Mengozzi indicates, national courts can apply EU law consistently with national conceptions of what is or is not acceptable collective action. ${ }^{67}$ It has equally obvious disadvantages. Without further specification, it is too vague to be applied to the enormous diversity which collective action takes (ranging from normal collective bargaining to workplace occupations). It will give rise to great divergences in the practice of national courts, both probably within national systems and certainly between national systems. Collective action in one Member State may be deemed an unacceptably disproportionate restriction on Community economic freedoms while identical collective action in another Member State is considered a wholly acceptable restriction. Not least, such divergences will inevitably give rise to references to the ECJ questioning national courts' application of the criteria. 68

In contrast, Advocate General Maduro's Opinion in Viking never even uses the word "proportionality". Instead, Advocate General Maduro proposes to legitimize autonomous collective action under certain conditions. ${ }^{69}$ There are two criteria: (i) for national

67 Para. 80: “...it is necessary to distinguish between the right to resort to collective action and the means of exercising it, which may differ from one Member State to another and do not automatically enjoy the protection enjoyed by that right itself...". But see also para. 142: “"...the interpretation of national law in conformity with Community law which the national court might adopt should not lead it to impair the very substance of the right to take collective action to defend the interests of workers, which, in my preliminary observations above, I have recognised as constituting a general principle of Community law, also upheld by the Swedish Constitution". See also para. 76 referring to Article 28 of the EU Charter on the right to take collective action, including strike action, and the permitted limitations in Article 52(1) of the Charter.

68 The lessons of the Acquired Rights Directive 1977 and the definition of "transfer of an undertaking" are all too plain to see. Council Directive 77/187 of February 14, 1977 on the approximation of the laws of the Member States relating to the safeguarding of employees' rights in the event of transfers of undertakings, businesses or parts of businesses, OJ L 61/26, as amended by Directive 98/50/EC of 29 June 1998, OJ L 201/88. Consolidated in Directive 2001/23 of 12 March 2001, OJ L/82/16.

69 In more general terms, to balance the risk of social dumping, Advocate general maduro invokes the so-called "social contract". Para. 59: "Although the Treaty establishes the common market, it does not turn a blind eye to the workers who are adversely affected by its negative traits. On the contrary, the European economic order is firmly anchored in a social contract: workers throughout Europe must accept the recurring negative consequences that are inherent to the common market's creation 
collective action: timing is everything; action before relocation is lawful; 70 action after relocation is unlawful ${ }^{71}$ as partitioning the labour market, a form of discrimination on grounds of nationality prohibited by EU law. ${ }^{72}$; (ii) for transnational collective action: solidarity must be voluntary. ${ }^{73}$

of increasing prosperity, in exchange for which society must commit itself to the general improvement of their living and working conditions, and to the provision of economic support to those workers who, as a consequence of market forces, come into difficulties. As its preamble demonstrates, that contract is embodied in the Treaty". This is admirable sentiment but it is both legally questionable under present Treaty provisions and somewhat unrealistic in the present political climate. It is also at odds with international conventions and constitutional traditions which look to autonomous collective action as the main protection of workers interests.

70 Para. 66: "Thus, in principle, Community law does not preclude trade unions from taking collective action which has the effect of restricting the right of establishment of an undertaking that intends to relocate to another Member State, in order to protect the workers of that undertaking". Para. 67: "...collective action to persuade an undertaking to maintain its current jobs and working conditions... represents a legitimate way for workers to preserve their rights and corresponds to what would usually happen if relocation were to take place within a Member State".

71 Para. 67: "However, collective action to persuade an undertaking to maintain its current jobs and working conditions must not be confused with collective action to prevent an undertaking from providing its services once it has relocated abroad. The first type of collective action represents a legitimate way for workers to preserve their rights and corresponds to what would usually happen if relocation were to take place within a Member State. Yet, that cannot be said of collective action that merely seeks to prevent an undertaking that has moved elsewhere from lawfully providing its services in the Member State in which it was previously established". The last sentence seems directly to contradict the policy of both the Posting Directive (Directive 96/71/EC concerning the posting of workers in the framework of the provision of services. OJ 1996, L18/1) and the Services Directive. Both allow the host Member State to enforce domestic labour standards. Why should trade unions not be allowed to take collective action in their own Member State against undertakings which have relocated and now seek to provide services in the host Member State?

72 Para. 62: "A coordinated policy of collective action among unions normally constitutes a legitimate means to protect the wages and working conditions of seafarers. Yet, collective action that has the effect of partitioning the labour market and that impedes the hiring of seafarers from certain Member States in order to protect the jobs of seafarers in other Member States would strike at the heart of the principle of non-discrimination on which the common market is founded".

73 Paras. 70-72; "Naturally, the FSU may, together with the ITF and other unions, use coordinated collective action as a means to improve the terms of employment of seafarers throughout the Community. A policy aimed at coordinating the national unions so as to promote a certain level of rights for seafarers is consistent with their right to collective action. In principle, it constitutes a reasonable method of counter-balancing the actions of undertakings who seek to lower their labour costs by exercising their rights to freedom of movement. One must not ignore, in that regard, the fact that workers have a lower degree of mobility than capital or undertakings. When they cannot vote with their feet, workers must act through coalition. The recognition of their right to act collectively on a European level thus simply transposes the logic of national collective action to the European stage. However, in the same way as there are limits to the right of collective action when exercised at the national level, there are limits to that right when exercised on a European level. A policy of coordinated collective action could easily be abused in a discriminatory manner if it operated on the basis of an obligation imposed on all national unions to support collective action by any of their fellow unions. It would enable any national union to summon the assistance of other unions in order to make relocation to another Member State conditional on the application of its own preferred stan- 


\section{A solution consistent with ILO standards in the context of the acquis communau-} taire social

The ECJ may seek a solution which accommodates the approaches adopted in the Opinions of the Advocates General in Viking and Laval. In very brief outline, this could involve the following five steps.

- In Viking, Advocate General Maduro takes the position that in cases of relocation, collective action is permitted to combat social dumping provided it is taken before the relocation occurs.

- Relocation is almost invariably accompanied by collective dismissals of workers. The ECJ in Case C-188/03, Junk, declared unequivocally that any decision to collectively dismiss workers can only be taken after the completion of the process of information and consultation. ${ }^{74}$

- Relocation between Member States will often be the action of multinational enterprises. European works councils (EWCs) have successfully taken legal action to block decisions by multinationals where the enterprise failed to comply with the requirements of the EWCs directive. ${ }^{75}$

- The conclusion, consistent with the reasoning of Advocate General Maduro in Viking, is that collective action should always be possible as any decisions affecting the workforce cannot be taken until the information and consultation requirements have been complied with. ${ }^{76}$

dards of worker protection, even after relocation has taken place. In effect, therefore, such a policy would be liable to protect the collective bargaining power of some national unions at the expense of the interests of others, and to partition the labour market in breach of the rules on freedom of movement. By contrast, if other unions were in effect free to choose, in a given situation, whether or not to participate in collective action, then the danger of discriminatory abuse of a coordinated policy would be prevented. Whether this is the situation in the circumstances of the present case must be left to the referring court".

74 Irmtraub Junk c. WolfgangKuhnel als Insolvenzverwalter uber das Vermogen der Firma AWO, Case C-188/03, 27 January 2005, paras. 40-45, interpreting Council Directive 75/129 of February 17, 1975 on the approximation of the laws of the Member States relating to collective dismissals, OJ L 48/29, as amended by Directive 92/56 of 24 June 1992, OJ L 245/92. Now consolidated in Council Directive 98/59/EC of 20 July 1998 on the approximation of the laws of the Member States relating to collective redundancies, OJ L 225/16.

75 Council Directive 94/45/EC of 22 September 1994 on the establishment of a European Works Council or a procedure in Community-scale undertakings and Community-scale groups of undertakings for the purposes of informing and consulting employees. OJ L 254/64 of 30.9.94. Council Directive 97/74/EC of 15 December 1997 extending to the United Kingdom Directive 94/45/EC. OJ L 10/22 of 16.1.98. There are three recent decisions of national courts in Belgium (British Airways, Cour de Travail de Bruxelles, 6 December 2006) and France (Gaz de France, Tribunal de Grande Instance et Cour d'Appel de Paris, 15 November 2006; Alcatel/Lucent, Tribunal de Grande Instance de Paris, 27 April 2007.

76 Not only the EWC Directive, but also Council Directive No. 2002/14 establishing a framework for informing and consulting employees in the European Community. OJ 2002, L80/29. 2002/14. 
- According to Advocate General Mengozzi in Laval, the balance between fundamental rights to collective action protected by the EU legal order and economic freedoms guaranteed by the Treaty is determined by the criterion of proportionality. This criterion has major defects as a matter of practical application by courts in different Member States. The ECJ should provide further guidance in the form of a criterion of "proportionality" inspired by Advocate General Maduro's Opinion in Viking. The criterion would be whether the employer had complied with the EU obligation to inform and consult prior to any decision, on relocation or on any other matter, requiring such a process of prior engagement with the workforce. Failure to do so would automatically make any resulting collective action proportionate.

This solution provides a criterion with both doctrinal and practical advantages. It is a specifically EU criterion of proportionality based on the acquis communautaire of EU Directives requiring information and consultation, Article 27 of the EU Charter (the fundamental right to information and consultation) and the transnational nature of enterprises and of collective action in the EU.

If complied with, it contributes to avoiding the negative consequences of both litigation (seeking remedies in the form of injunctions from national courts to enforce the obligation to inform and consult) and collective industrial action by workers. It is a solution which reconciles respect for the international labour law standards of the ILO with the specific context of the acquis communautaire social.

\section{Conclusion}

The ECJ's jurisdiction in labour law offers the prospect of consolidating the EU as a major player in the emerging legal order of globalisation. It becomes a leader, not a follower in the wake of the ILO and the WTO. EC labour law, by virtue of its character as a supranational law with supremacy over national labour laws, already partakes of the character of a higher norm. It is European as reflecting the cumulative experience of national labour laws, filtered through the prism of the EU institutions and refined in the crucible of the developing European polity. The EU Charter's labour rights, becoming part of an EU social constitution, would reinforce this status. The EU social constitution may become a model for international labour law. 


\title{
The Impact of National Labour and Social Law on the Law of the European Community
}

\author{
Niklas BRUUN
}

\section{Introduction}

There are two main channels through which national law can have an impact on the law of the European Community. The first is through legislation adopted by the Community institutions (regulations, directives, decisions etc.). The second is through the Court practice of the European Court of Justice (ECJ). I will comment on both.

I start with a simple distinction between three different types of EC law. This is followed by a discussion in the light of some examples of how national labour and social law influences the law of the European Community.

\section{Different types or categories of EC labour and social law}

- National labour laws harmonised through EC Directives or other instruments: The extensive EC regulation on health and safety forms one example of such harmonization. During such a legislative process of harmonization it is always possible that one or another country forms a model for the EC legislator, although in practice EC law usually is designed as a compromise between different national models.

- Regulation of the labour or social law aspects of cross-border or genuinely transnational phenomena involving labour in the internal market: European Works Councils, European Companies (SE), posting of workers, co-ordination of social security for workers who have been working in different Member States, etc.. Here the specific transnational feature of the regulation indicates that it cannot as such directly copy any national regulation.

- Indirect "regulation" is the third type of regulatory measures on EC level that have an impact on labour and social law: a strong internal market legal regime may restrict national labour and social law rights or practices; examples include competition law vs. collective agreements, economic rights to free movement vs. the right to collective bargaining and the right to resort to collective action, etc. Another kind of such indirect restriction is the prohibition of a trade union representative on a listed company's board of directors to discuss issues concerning 